\title{
PURIFICATION OF DAIRY WASTEWATERS BY ADVANCED OXIDATION PROCESSES AND MEMBRANE FILTRATION \\ ${ }^{1}$ M. Zakar, ${ }^{1}$ E. Lakatos, ${ }^{2}$ G. Keszthelyi-Szabó, ${ }^{2}$ Zs. László \\ ${ }^{1}$ Institute of Food Sciences, Széchenyi István University, H-9200 Mosonmagyaróvár, Lucsony str. 15-17. \\ ${ }^{2}$ Department of Process Engineering, Faculty of Engineering, University of Szeged, H-6724 Szeged, Moszkvai krt. 9. e-mail: zsizsu@mk.u-szeged.hu
}

\begin{abstract}
Membrane separation processes are space and cost-efficient, easy to scale-up operations, which have proved to treat food industrial wastewaters efficiently. Beside the advantages like high separation efficiency without any chemical changes and low energy-intensity, membrane filtration also has drawbacks, like decreased operational efficiency caused by flux decile resulting from fouling and concentration polarization. Combination of oxidation pre-treatment and membrane filtration is a promising method for decreasing fouling due to the physicochemical changes caused by pre-oxidation of the wastewater in structure of colloidal pollutants and in the interactions between the foulants and the membrane material. The aim of this work is to identify the parameters affecting the membrane fouling during treatment of dairy wastewaters, and present the current trends of research in this field.
\end{abstract}

Keywords: dairy wastewaters, membrane separation, advanced oxidation processes

\section{INTRODUCTION}

Water is used in most steps of food processing technologies, e.g. washing raw materials, cleaning, cooling and heating. Food industrial effluents typically contain high amounts of organic compounds e.g. proteins, carbohydrates, fats, and suspended solids. Among the food industries, dairy industry generates the largest volume of wastewater (from 0.2 to $10 \mathrm{~L}$ of effluent per litre of processed milk) due to large water consumption [1]. Other than organic and inorganic impurities dairy wastewaters contain detergents used for equipment cleaning [2] in varying quality and quantity throughout the day that changes with the seasons. These effluents have the following characteristics: biochemical oxygen demand (BOD), with an average ranging from 1,000 to $3,000 \mathrm{mg} / \mathrm{L}$ in the untreated effluent, chemical oxygen demand (COD) ranging from 2,000 to $5,000 \mathrm{mg} / \mathrm{L}$, total suspended solids (TSS) at 400-1,000 (mg/L), total dissolved solids (TDS): phosphorus $(10-30 \mathrm{mg} / \mathrm{L}$ ), and nitrogen (about $6 \%$ of the BOD level). Levels of potential contaminants in dairy wastewaters typically exceed the levels considered hazardous for domestic wastewaters [3]. They may contain microorganisms including pathogens, from contaminated materials or production processes, and they often generate odours and, in some cases, dust, which also need to be controlled [4].

The conventional treatments of these effluents include the use of primary physical treatments to remove solids, oils and fats, secondary biological treatment to remove organic matter and nutrients, but several problems have been reported, such as high production of scum, low sludge settleability, low flexibility of the technology, difficulties in removal of nutrients (nitrogen and phosphorus) and problems in the oil and fat degradation [5]. Because of the reduction in water availability and the increase in water treatment costs, there are several researches for developing new technologies for wastewater treatment, not only aiming to meet the standards but also to obtain treated effluents feasible for reuse. Considering these, membrane separation techniques seem to be promising processes for the treatment of dairy industrial wastewaters. This work aims to collect results from recent studies of membrane filtration and advanced oxidation processes in relation to the applicability of these processes in purification of dairy wastewaters.

\section{MEMBRANE SEPARATION OF DAIRY INDUSTRIAL WASTEWATERS}

Several researches focused on membrane filtration treatment of dairy effluents concluded that microfiltration (6], ultrafiltration (UF) [4], nanofiltration (NF) [7], reverse osmosis (RO) [1] or two-stage operations such as UF+NF [8] may be appropriate methods to produce reusable water. Membrane 
treatment of dairy wastewaters with the aim of water reuse could simultaneously lower the total water consumption and the effluent production of the dairy plant, as the purified water produced by membrane treatment could be reused in the dairy factory as heating or cooling water, as boiler make-up water or for cleaning purposes.

Beside the advantages like high separation efficiency without any chemical changes and low energyintensity, membrane filtration also has drawbacks [9]. The main disadvantage is the decreased operational efficiency caused by flux decile resulting from fouling and concentration polarization. Although the polymer-based membranes are cheap and available, their life time is limited and they require regular cleaning.

Eliminating contaminants from high turbidity wastewaters or removal of microorganisms can be realized by means of microfiltration and ultrafiltration due to their relatively low energy consumption and high initial flux. Microfiltration membranes possess significantly higher flux at a lower transmembrane pressure but lower retention compared to ultrafiltration membranes, and are also more prone to be fouled [10].

\subsection{Membrane fouling components}

Depending on the relative size of the particles and membrane pores, fouling can arise as complete or partial pore blockage or as formation of a deposited layer on the membrane surface. Beside these direct interactions between the colloidal particles and the membrane causing irreversible (non-washable) resistance during filtration, the particle-particle interactions result in washable cake/concentration polarization layer built up from retained colloidal particles at the membrane surface (Fig.1.). This causes a reversible resistance to fluid flow [11].

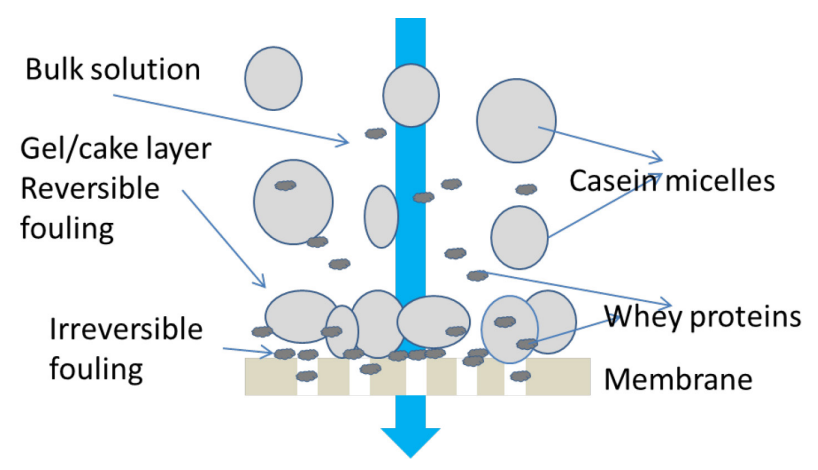

Figure 1. Fouling phenomena of milk proteins during UF [11]

Colloidal particles are clogging the membrane surface through physical and chemical interactions. Hydrodynamic driving forces applied during the filtration deliver the fouling particles to the surface, while binding to the surface is determined by colloidal interactions. Clogging of the membrane depends on the material, physical properties, and geometry of the membrane; pore size; roughness [12]; hydrodynamic conditions and the chemical nature of the foulants.

Various matters may cause fouling; in this work, the fouling propensity of typical dairy effluents are discussed. Dairy wastewaters contain the organic compounds of milk: proteins, fats, carbohydrates (lactose), minerals containing a high variety of salts e.g. sodium, potassium, calcium, magnesium, phosphate, chloride, sulphate, carbonate, and citrate [11,13] (Table 1). 
Table 1. Characteristics of the milk proteins related to membrane fouling propensities [13]

\begin{tabular}{|c|c|c|c|c|c|}
\hline Proteins/Membrane material & $\begin{array}{l}\text { Concentration } \\
\text { in milk }(\mathrm{g} / \mathrm{L})\end{array}$ & Size $(\mathrm{kDa})$ & Size (nm) & IEP & $\begin{array}{l}\text { Charge in } \\
\text { neutral } \mathrm{pH}\end{array}$ \\
\hline \multicolumn{6}{|l|}{ Caseins } \\
\hline$\alpha_{\mathrm{s} 1}-$ casein $\left(\alpha_{\mathrm{s} 1}-\mathrm{CN}\right)$ & $12-15$ & 23.6 & \multirow{4}{*}{$\begin{array}{l}\text { form casein } \\
\text { micelles } \\
(50-300 \\
n m)\end{array}$} & 4.96 & negative \\
\hline$\alpha_{\mathrm{s} 2}$-casein $\left(\alpha_{\mathrm{s} 2}-\mathrm{CN}\right)$ & $3-4$ & 25.2 & & 5.27 & negative \\
\hline$\beta$-casein $(\beta-\mathrm{CN})$ & $9-11$ & 24.0 & & 5.2 & negative \\
\hline$\kappa$-casein $(\kappa-\mathrm{CN})$ & $2-4$ & 19.0 & & 5.54 & negative \\
\hline \multicolumn{6}{|l|}{ Whey proteins } \\
\hline$\beta$-lactoglobulin ( $\beta$-LG) & $2-4$ & 18.3 & $3-8 \mathrm{~nm}$ & 4.6 & negative \\
\hline$\alpha$-lactalbumin $(\alpha-\mathrm{LA})$ & $0.6-1.7$ & 14.2 & & 5.35 & negative \\
\hline bovine serum albumine BSA & 0.4 & 66.4 & & 4.7 & negative \\
\hline Immunoglobulin $\mathrm{G}$ IgG & 0.4 & $150-1000$ & & $6.1-8.5$ & $\begin{array}{l}\text { negative/ } \\
\text { positive }\end{array}$ \\
\hline \multicolumn{6}{|l|}{ Membrane material } \\
\hline Polysulfone (PS) & & & & 3.6 & negative \\
\hline Polyethersulfone (PES) & & & & $2.2-2.4$ & negative \\
\hline
\end{tabular}

Beside the natural components dairy wastewaters intermittently may contain detergents. Several studies have been performed to identify the components contributing to fouling in milk ultrafiltration. Caseins generally have an open structure, and most of them are present in milk as casein micelles (CMs); at native $\mathrm{pH}$ and room temperature, about $95 \%$ of caseins are associated as colloidal assemblies of micelles. The exact structure of the CM is not known, however it is generally accepted that $\kappa$-casein is located on the micelle exterior, its long hydrophilic sections extend into the serum, providing a $\sim 7 \mathrm{~nm}$ thick layer that sterically stabilises casein micelles. [11]. Their size is ranging $50-300 \mathrm{~nm}$ in diameter [14]. Unlike caseins, whey proteins generally have tertiary and quaternary structures, which can influence concentration polarization and fouling behaviour of milk. Whey protein ( $\beta$-lactoglobulin) exists as dimers held together by hydrophobic interactions (Lewis-acid-base interactions), but also exhibits different aggregation states depending on the $\mathrm{pH}$. The most important mineral in milk is calcium phosphate, which is sparingly soluble, forms complex associations of calcium with other salts and milk components (like free caseins, citrates, and lactose) $[15,16]$, and stabilisation of calcium phosphate is provided by the presence of CMs.

\subsection{Interactions between the membrane and pollutants}

The membrane characteristics are changing by interactions between colloidal particles of the wastewater and the membrane, e.g. protein adsorption and mineral precipitation. The resultant fouled membrane has different physicochemical properties compared to the clean membrane, e.g. changed surface charge, [17] and reduced pore size.

Earlier studies $[18,19,20]$ have shown that in case of polymer membranes, irreversible fouling is caused mainly by proteins and not by minerals during the ultrafiltration of milk. Within the protein fraction whey proteins are the dominant foulants [21], due to their size (Fig.1.). The comparison of MF and UF studies on whey proteins indicated, that flux decline is greater during MF than UF [22, 23] due to the potentially poreblocking particles for MF resulted in protein aggregation. Since both the original and the aggregated particles are retented by UF, ultrafiltration membranes cannot be fouled by them.

During filtration, proteins can adsorb directly onto the membrane surface. The phenomenon is determined by the (1) electrostatic interactions, as charge distribution on protein-surface contact, and (2) Van der Waals interactions, as hydrophobic interactions releases the water and ions from the protein and membrane 
$[20,24]$. Proteins are amphoteric molecules, their surface charge (characterized by Zeta potential) strongly depends on $\mathrm{pH}$ of the solute (Table 1). In neutral solutions, major milk proteins and most of the polymeric membranes used in dairy industry are negatively charged. Since the interaction between proteins and membrane-proteins are repulsive; the presence of protein adsorption onto mainly hydrophobic surfaces indicates that the hydrophobic interactions are the dominant over the electrostatic interactions.

\section{REDUCTION OF MEMBRANE FOULING}

Membrane fouling can be reduced both by physical and chemical methods. Physical methods may be optimizing flow conditions at the surface of the membrane (e.g. stirring) or application of ultrasound or vibration [25]. Physicochemical or chemical methods aim to change the characteristics the membrane by modification of the surface [26] or modification of the colloidal-size particles (both hydrophilic and hydrophobic properties, the surface charge and the size), converting them to a form which cannot bind to the membrane surface, and/or can form associations of a size which are unable to penetrate the pores of the membrane [27].

\subsection{Application of advanced oxidation processes}

The combination of membrane separation and pre-treatment with advanced oxidation processes (like ozone, hydrogen peroxide, UV light and their combination) opens new opportunities, since the ozone and the resulting oxidizing (mainly hydroxyl-) radicals are efficiently changing the characteristics of the colloidal particles or are oxidizing compounds, which cause membrane fouling. Today, environmental legislations require new wastewater treatment technologies, which possess enhanced purification efficiency using less chemicals and producing fewer by-products. Advanced oxidation processes and ozone treatment meets these requirements, as they generate free radicals, which are able to react with the contaminants directly and indirectly, and finally decomposes to oxygen. In these reactions two typical pathways were observed, influencing membrane filtration parameters: (1) the micro-flocculating effect producing associated colloidal particles, and (2) degradation of organic materials (Fig.2.). The latter decreases the retention of pollutants and may increase the pore fouling. Short-term ozone pre-treatment leads to microflocculation, and results in large associations, thereby reducing membrane fouling $[28,29]$.

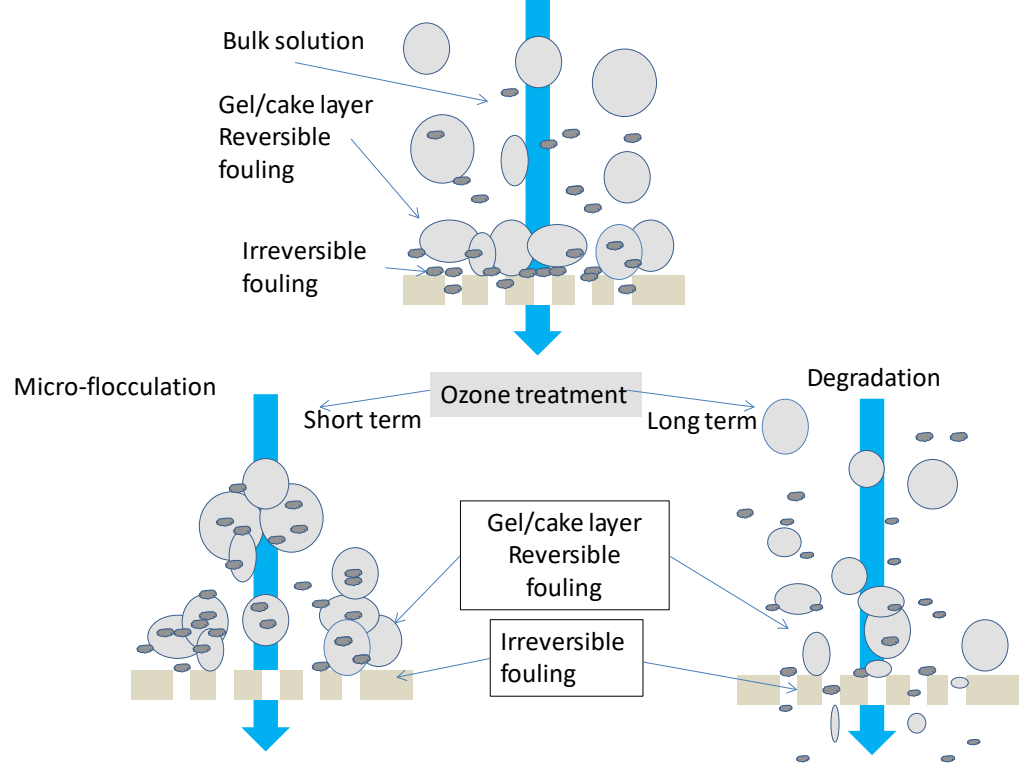

Figure 2. Possible effect of ozone pre-treatment on membrane filtration of dairy wastewaters 
Laszlo et al. [30] investigated the applicability of membrane filtration (NF) in combination with preozonation in surfactant containing dairy wastewater treatment technology. The combination of preozonation and membrane filtration was able to reduce the surfactant content of the wastewater below the legally regulated limit. It was found that preozonation decreased the flux and increased the COD and surfactant removal efficiencies. Greatly enhanced biodegradability of the retentate also was observed. The explanation of these results may be related to the microflocculation effect of preozonation of organic matter and to reaction between the components present in dairy wastes, the ozonation by-products and metal ions e.g., calcium (present in considerable amount in dairy wastewaters) may preclude the formation of aggregates.

Several researchers have found that ozone pre-treatment increases the flux of effluents containing natural organic compounds, proteins, or oil emulsion [27,31]. Ozone treatment oxidizes the molecules (double bonds or the aromatic rings are decomposed) - a number of oxidized functional group $(-\mathrm{OH},=\mathrm{O}$ and $\mathrm{COOH}$ ) appear on them. Negative surface charge of the colloidal particles is increased due to the acid-base balance of these carboxyl groups with water. This means that in case of hydrophobic membranes the role of Van der Waals interactions is suppressed, while in case of hydrophilic membranes the electrostatic repulsion increases between the negatively charged membrane and the particles - both reduces membrane fouling and finally increases flux [32]. Earlier studies showed that the ozone pre-treatment has changed the fouling mechanism due to microflocculation: instead of pore fouling reversible cake/gel layer appears, resulting in decreased irreversible filtration resistances and increased reversible resistances [29].

In order to avoid flux decline during filtration, the fouling mechanism should be modified; to this end it should be taken into account that coagulation of proteins, the reactions and decomposition of ozone are all strongly $\mathrm{pH}$ dependent. At higher $\mathrm{pH}$ the reaction rate of ozone decomposition is higher, while fouling is decreased. It also should be considered that the minerals of dairy wastewaters (mainly the calcium and magnesium ions) influence the size and stability of floccules, [27]; however, their role and mechanism of membrane filtration should be clarified.

\section{CURRENT TRENDS AND QUESTIONS TO BE ANSWERED}

Earlier studies indicate that preozonation may enhance the treatability of dairy wastewaters with membrane filtration. However, the industrial application requires further large scale experiments to optimize the ozone dosage and the ozonation time [33], moreover the clarification of exact mechanism of the oxidation reactions and its effects on membrane-solute interactions determining fouling is necessary.

In recent years, several methods were applied to characterize the fouling layer, especially the membranefouling layer interface, which has key importance in the design of pre-treatment and operational procedure, as well as optimization of cleaning processes of fouled membranes. Parameters of the membrane surface that affect fouling are hydrophilicity, roughness, charge, surface free energy and steric hindrance or repulsion. Besides methods based on physicochemical properties (zeta-potential, contact angle or surface free energy measurements) a range of techniques were applied to characterize membrane fouling layer, such as, scanning electron microscope (SEM), X-ray photoelectron spectroscopy (XPS) and infrared (IR) spectroscopy [34]. These methods may be powerful methods to obtain new information about the nature of membrane-foulant interactions, and by now only few publications can be found, which aim the investigation of the effect of pre-treatment on these parameters [20].

\section{SUMMARY}

Membrane processes used for the purification of dairy wastewaters containing proteins, carbohydrates, minerals, or detergents are studied. The applications of these processes in dairy industry are limited due to 
membrane fouling. For more fundamental understanding of the mechanism of fouling and hence to develop appropriate methods which can prevent the membrane fouling the characterization of fouling is necessary. Combination of oxidation pre-treatment and membrane filtration is a promising method for purification of food industrial wastewaters, including dairy wastewaters, since previous results have shown that both the flux and the cleaning efficiency can be increased. However, to develop an industrial application of the process several issues need to be clarified, such as appropriate ozone dose, the operational parameters of ozone treatment, or the effect of pre-treatment on the interactions between the membrane-solvent-pollutant, which determine the membrane fouling mechanism.

\section{ACKNOWLEDGEMENTS}

This project was supported by the János Bolyai Research Fellowship of the Hungarian Academy of Sciences. The authors are also grateful for the financial support provided by the project Hungarian Scientific Research Fund (NFKI contract number K112096).

\section{REFERENCES}

[1] M. Vourch, B. Balance, B. Chaufer, G. Dorange, Treatment of dairy industry wastewater by reverse osmosis for water resue. (2008), Desalination, 219:190-202.

[2] M. Perle, S. Kimchie, G. Shelef, Some biochemical aspects of the anaerobic degradation of dairy wastewater. Water Res., (1995), 29, p. 1549-1554.

[3] A. Bick, T.J.G. Plazas, F. Yang, A. Raveh, J. Hagin, G. Oron, Immersed Membrane Bio Reactor (IMBR) for treatment of combined domestic and dairy wastewater in an isolated farm: An exploratory case study implementing the Facet Analysis (FA). (2009), Desalination, 249, p.1217-1222.

[4] B. Sarkar, P.P. Chakrabarti, A. Vijaykumar, V. Kale, Wastewater treatment in dairy industries: possibility of reuse, Desalination, (2006), 195:141-52.

[5] L.H. Andrade, G. E. Motta, M. C. S. Amaral, Treatment of dairy wastewater with a membrane bioreactor, Brazilian Journal of Chemical Engineering, (2013), Vol. 30, No. 04, pp. $759-770$.

[6] V. Yip. S.D. Arntfield. A.W. Hydamaka, Potential for Stainless Steel Microfiltration Processing to Reduce Effluent from a Fluid Milk and Ice Cream Processing Plant, Journal of Dairy Science, (1996), April, Volume 79, Issue 4, Pages 710-716.

[7] I. Koyuncu, M. Turan, D. Topacik, A. Ates, Application of low pressure nanofiltration membranes, for the recovery and reuse of dairy industry effluents, Water Sci. Tech., (2000), 41(1) 213-221.

[8] J. Luo, L. Ding, B. Qi, M.Y. Jaffrin, Y. Wan, A two-stage ultrafiltration and nanofiltration process for recycling dairy wastewater, Bioresour. Technol., 102 (2011), pp. 7437-7442.

[9] B.K. Bélafiné, Membrános Mủveletek,Veszprémi Egyetemi Kiadó, Veszprém (2002)

[10]Qibing Chang, Jian-er Zhou, Yong qing Wang, Jian Liang, Xiao zhen Zhang, Sophie Cerneaux, Xia Wang, Zhi wen Zhu, Ying chao Dong Application of ceramic microfiltration membrane modified by nano-TiO2 coating separation of a stable oil-in-water emulsion, Journal of Membrane Science (2014), 456:128-133.

[11] K.S.Y. Ng, M. Haribabu, D.J.E. Harvie, D.E. Dunstan, G.J.O. Martin, Mechanism of flux decline in skim milk ultrafiltration: A review, J. Membr. Sci. 523 (2017), 144-162.

[12]E. M. Vrijenhoek, S. Hong, M. Elimelech, Influence of membrane surface properties on initial rate of colloidal fouling of reverse osmosis and nanofiltration membranes, J Membr Sci, 188 (2001), 115$128 \mathrm{P}$.

[13] Walstra, J.T.M. Wouters, T.J. Geurts, Dairy Science and Technology Second Edition (2006)

[14]D.G. Dalgleish, M. Corredig, The structure of the casein micelle of milk and its changes during processing, Annu. Rev. Food Sci. Technol., 3 (2012), pp. 449-467.

[15]G. Brule, E. Real del Sol, J. Fauquant, C. Fiaud, Mineral salts stability in aqueous phase of milk: influence of heat treatments, J. Dairy Sci. 61 (1978), 1225-1232. 
[16]P. Charley, P. Saltman, Chelation of calcium by lactose: its role in transport mechanisms, Science 139 (1963), 1205-1206 (80-)

[17] A. Bouchoux, P. Qu, P. Bacchin, G. Gésan-Guiziou, A general approach for predicting the filtration of soft and permeable colloids: the milk example, Langmuir 30 (2014), 22-34.

[18]L. Bégoin, M. Rabiller-Baudry, B. Chaufer, C. Faille, P. Blanpain-Avet, T. Bénézech, et al., Methodology of analysis of a spiral-wound module. Application to PES membrane for ultrafiltration of skimmed milk, Desalination, 192 (2006), pp. 40-53.

[19]M. Koutake, Y. Uchida, T. Sato, K. Shimoda, A. Watanabe, S. Nakao, Filtration membrane fouling in ultrafiltration of skim milk, 1: causes and cleaning, J. Agric. Chem. Soc. Jpn., 61 (1987), pp. 677-681.

[20]M. Rabiller-Baudry, M. Le Maux, B. Chaufer, L. Begoin, Characterisation of cleaned and fouled membrane by ATR---FTIR and EDX analysis coupled with SEM: application to UF of skimmed milk with a PES membrane, Desalination, 146 (2002), pp. 123-128.

[21]P.S. Tong, D.M. Barbano, M.A. Rudan, Characterization of proteinaceous membrane foulants and flux decline during the early stages of whole milk ultrafiltration, J. Dairy Sci. (1988), pp. 604-612.

[22] S.T. Kelly, A.L. Zydney, Mechanisms for BSA fouling during microfiltration, J. Membr. Sci., 107 (1995), pp. 115-127.

[23]T. Steinhauer, M. Marx, K. Bogendörfer, U. Kulozik, Membrane fouling during ultra- and microfiltration of whey and whey proteins at different environmental conditions: the role of aggregated whey proteins as fouling initiators, J. Membr. Sci., 489 (2015), pp. 20-27.

[24]T. Lin, Z. Lu, W. Chen, Interaction mechanisms and predictions o membrane fouling in an ultrafiltration system, using the XDLVO approach, J Membr Sci, 461 (2014), 49-58.

[25] L.L.A. Koh, H.T.H. Nguyen, J. Chandrapala, B. Zisud, M. Ashokkumar, S.E. Kentish, The use of ultrasonic feed pre-treatment to reduce membrane fouling in whey ultrafiltration, J Membr Sci, 453 (2014), 230-239.

[26] L. Benavente, C. Coetsier, A. Venault, Y.Chang, C. Causserand, P. Bacchin, P. Aimar, FTIR mapping as a simple and powerful approach to study membrane coating and fouling, J. Membr. Sci. 520 (2016), 477-489.

[27] S. Van Geluwe, L. Braeken, B. Van der Bruggen, Ozone oxidation for the alleviation of membrane fouling by natural organic matter: A review, (2011), Water Res. 45:3551-3570.

[28]H.T. Zhu, X.H. Wen, X. Huang, Pre-ozonation for dead-end microfiltration of the secondary effluent: suspended particles and membrane fouling, (2008), Desalination 231:166-174.

[29]Z. Laszlo, S. Kertesz, S. Beszedes, Z. Hovorka-Horvath, G. Szabo, C. Hodur, Effect of pre ozonation on the filterability of model dairy waste water in nanofiltration, (2009), Desalination, 240: 170-7.

[30]Z. Laszlo, S. Kertesz, E. Mlinkovics, C. Hodur, Dairy waste water treatment by combining ozonation and nanofiltration, Separation Science and Technology, (2007), 42(7): 1627-37.

[31]Zs. Kiss, L. Kocsis, G. Keszthelyi-Szabó, C. Hodúr, Zs. László, Treatment of oily wastewater by combining ozonationand microfiltration, (2014), Desalination and Water Treatment 55/13:3662-3669.

[32]S.T. Nguyen, F.A. Roddick, Pre-treatments for removing colour from secondary effluent: Effectiveness and influence on membrane fouling in subsequent microfiltration, Separation and Purification Technology (2013), 103:313-320.

[33] C.P. O’Donnell, B.K. Tiwari, P.J. Cullen, R.G. Rice,(edited by), Ozone in Food Processing, WileyBlackwell Publishing Ltd., 2012

[34] S. Suwal, A. Doyen, L. Bazinet, Characterization of protein, peptide and amino acid fouling on ionexchange and filtration membranes: Review of current and recently developed methods. J. Membr. sci. (2015), 496 267-283. 